\title{
Miranda
}

Revue pluridisciplinaire du monde anglophone /

Multidisciplinary peer-reviewed journal on the English-

speaking world

$4 \mid 2011$

Samuel Beckett : Drama as philosophical endgame?

\section{Louise Penner, Victorian Medicine and Social Reform: Florence Nightingale among the Novelists}

\section{Laurence Talairach-Vielmas}

URL: http://journals.openedition.org/miranda/2184

DOI: 10.4000/miranda.2184

ISSN: 2108-6559

Publisher

Université Toulouse - Jean Jaurès

\section{Electronic reference}

Laurence Talairach-Vielmas, "Louise Penner, Victorian Medicine and Social Reform: Florence Nightingale among the Novelists", Miranda [Online], 4 | 2011, Online since 24 June 2011, connection on 16 February 2021. URL: http://journals.openedition.org/miranda/2184 ; DOI: https://doi.org/10.4000/miranda.2184

This text was automatically generated on 16 February 2021.

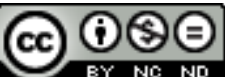

Miranda is licensed under a Creative Commons Attribution-NonCommercial-NoDerivatives 4.0 International License. 


\title{
Louise Penner, Victorian Medicine and Social Reform: Florence Nightingale among the Novelists
}

\author{
Laurence Talairach-Vielmas
}

\section{REFERENCES}

Louise Penner, Victorian Medicine and Social Reform: Florence Nightingale among the

Novelists (New York: Palgrave Macmillan, 2010), 193 p, ISBN 978-0-230-61595-3

Much social activism went on in the Victorian period, and quite a few social reformers were women. These female social reformers were even fictionalized and satirized, as Mrs Jellyby in Bleak House (1854), Dickens's obsessive philanthropist who focuses so much on Africa that she forgets to look after her house, children and husband. Florence Nightingale was one of these activists. The nurse who became famous for her involvement in the Crimean War was a highly significant Victorian public figure. Yet, the image of the public figure of Nightingale sometimes appears paradoxical. Nightingale may be the heroine of the Crimean War-the self-sacrificing "lady of the lamp"-, she may embody the struggles for the professionalization of nursing or she may be seen as a fame-seeking opportunist. Penner's Victorian Medicine and Social Reform: Florence Nightingale among the Novelists does not offer a new biography of Nightingale. It focuses on Nightingale's public and private writings, such as Notes on Nursing (1860) or Notes on Nursing for the Poor (1861) and analyses the relationship between her writings and the social and medical policies in Victorian Britain, examining the potential influences of the rhetorical and narrative strategies of Condition of England novels, sensation novelists or realistic novelists, whose works denounced the medical, social and economic problems which plagued Victorian society. Nightingale was close to George Eliot, Charles Dickens, and Elizabeth Gaskell, and the influence of her writings may be traced in works by Gaskell, Eliot, Dickens, but also Wilkie Collins and Hesba Stretton. As Penner argues, studies looking at the 
development of the Victorian novel have too often contextualised Victorian realism through connecting narratives and rhetorical strategies to social and political writings by male military, political, medical or philosophical figures, from Edwin Chadwick to John Stuart Mill. However, since the publication of MacDonald's Collected Works of Florence Nightingale, it stands to reason that Nightingale's writings and close relationships with key literary, social, political or even medical figures of the period must have been far more influential than generally acknowledged.

2 Nightingale's combat to explain that germs were not devilish creatures from superstitious tales and legends, and her reformist ideas and methods have so far been underappreciated.

In Chapter 1, Penner underlines the power of Nightingale's writing to influence public beliefs and behaviours through using a sensational rhetoric very similar that that found in mid-Victorian popular narratives. To do so, Penner compares Nightingale's Notes on Nursing with Wilkie Collins's The Woman in White (1859-60). Nightingale's Notes on Nursing and the third edition of Notes on Hospital coincided with the rise in popularity of sensation fiction, a literary genre aimed at provoking physical reactions in readers. Interestingly enough, these reactions were closely related to contemporary social or medical problems. Penner shows that Nightingale's exploitation of the fear of contagion in Notes on Nursing is much closer to the style found in sensation novels than to her rhetoric in Notes on Hospitals. Nightingale believed in the training of women in sanitary science and in the advancement of sanitary principles at home. In Notes on Nursing, she offers readers sanitary guidelines for home management: her female readers must not only see household management as heroic work, but also develop neutral and empiricist modes of observation to perform their home duties correctly. Advocating the model of a detached, empirical observation to fight metaphysical presuppositions about disease, Nightingale's voice is very close to the narrative voice of Wilkie Collins's detective, Walter Hartright, in The Woman in White. Because sensation novels aimed to fight criminality by developing rational observation, Penner traces Nightingale's ideas on household management, contagion, or even the care for invalids, in Collins's novel, focusing on the narrative technique and on revealing characters, such as the hyperchondriac invalid, Frederick (not Arthur, as argued) Fairlie, whose ideas on cleanliness recall Nightingale's. Dusting off the language of contagion to dismiss popular perceptions of disease, Nightingale's sensational rhetoric has a view to raising her reader's awareness of sanitation issues in the same way as sensation novels were often criticized for being novels "with a purpose".

Chapter 2 focuses on Nightingale's Poor Law writing which she parallels with Dickens's and Hesba Stretton's reformist narratives, since Nightingale was known to have distributed Dickens's and Stretton's works to nurses and soldiers alongside her own work. To examine Nightingale's reformist work and her exposure of the flaws in the workhouse system, Penner looks at Nightingale's engagement in Poor Law reform and philanthropy from the late 1840s through the late 1870s. Though Nightingale was reluctant to use her public image and disliked many pictures of heroic philanthropy in women, she nonetheless endorsed a few fictional and non-fictional narratives of female philanthropy. These narratives, Penner contends, "[reflect] a calculated strategy on her part to move the public to agitate for the poor in the ways she saw as most effective" (40). Dickens's and Stretton's works present two types of philanthropy which appealed to Nightingale: successful individual middle-class efforts at philanthropy and portraits 
of the poor fighting for reform in their own communities. Nightingale disliked portraits of self-sacrificing female philanthropists, much satirized in the press and in fiction, as well as sensational stories recording workhouse conditions, which if they raised public awareness, had however no influence upon government officials. More than inciting individuals to fight for workhouse reform, Nightingale asked for government participation, not so much in terms of public spending but in furnishing the means for paupers to work themselves out of poverty. The type of non-fictional books Nightingale donated to nurses, soldiers and charities ranged from biographies of social reformers to works by women advocating housing, educational or penal reforms in Britain and India (Octavia Hill, Mary Carpenter). In the field of fiction, Nightingale turned towards Dickens, whom she admired and with whom she had worked on the Committee of the Association for Improving Workhouse Infirmaries), and Hebba Stretton, whose works were published in Dickens's Household Words. Penner looks at Bleak House and Bede's Charity, and examines their portraits of household managers and at the models of charity which Nightingale believed could reform society.

Chapter 3 explores Nightingale's reactions to reformist ideas in intellectual circles, particularly as revealed in George Eliot's fiction. Penner fights assumptions about Nightingale which generally see her as advocating women's suffrage and opening medical education for women, and tries to understand Nightingale's reaction towards George Eliot's portrait of Dorothea in Middlemarch. In fact, if Nightingale did not believe that the cause in favour of women having access to medical education should be defended, she nevertheless believed that women could influence medicine. Middlemarch reflects nineteenth-century scientific, medical and philosophical issues, and Eliot was known to have thoroughly researched pathological anatomy and medical theories about disease origins and transmissions. However, the principles of Lydgate's research counteracted those of sanitary science, since Eliot mocks the relevance of statistics in medicine as inefficient ways of gauging health-worse, medical statistics are even connected to issues of contagion. So Penner argues that Nightingale's reaction might be explained through Eliot's view of scientific advancement in medicine: Lydgate works from theories and his views on medical research and practice belittle the importance of sanitary science which Nightingale was advocating, jeopardizing therefore Nightingale's vision of women's contributions to the health of the nation through their involvement in nursing and midwifery. In Middlemarch, contagion is never a matter of environmental pollutants, even if Eliot's irony or sarcasm may cast doubt on what she really meant. Lydgate's microscopical researches may have been influenced by the development of germ theories in the late 1860s, challenging the single-fever theory (crucial to anticontagionist proponents such as Nightingale).

Chapter 4, on the 1876 Madras famine, brings to light the way in which Nightingale attempted to raise British sympathies towards Indian natives through changing the rhetorical and narrative strategies of her public writings about famine in India. Nightingale did not merely try to combat sanitary problems; she highlighted the implication of the Indian colonial government in the production of famine conditions through focusing "her writings of the 1870s on issues of irrigation and exploitative land and money-lending policies" (112). Yet, familiarizing British readers with the lives of the Ryots through mental pictures soon proved unsatisfactory and did not ensure sympathetic identification with the Indian natives. This is the reason why, Penner argues, Nightingale turned towards the narrative strategies of the 1840 s and 1850 s Condition of England novels and the way they represented urban poverty and epidemic 
disease in industrial England. Penner looks at Harriet Martineau's and Edwin Chadwick's influence, explains how Nightingale was also perhaps inspired by travel writers to India in the way she represented the Indian peasantry, and offers close looks at Gaskell's Mary Barton (1848) to underline the parallels between Gaskell's and Nightingale's rhetorical and narrative strategies. In particular, she stresses how Nightingale presents self-help as a form of heroism, ideas which Gaskell had developed in her social problem novel.

7 Victorian Medicine and Social Reform: Florence Nightingale among the Novelists is an original addition to the Nightingale scholarship which sees beyond stereotypical representations of the famous Crimean War heroine. Through looking closely at Nightingale's writings, Penner offers a portrait of the reformist and makes explicit how she addressed health and social problems by recurrently adapting her rhetoric to her reading public. Though readers should not turn to Penner's work for a biography of Nightingale, the parallels she draws between her writings and sensational rhetoric and themes or her reading of Middlemarch will not fail to captivate students and scholars interested in such a significant Victorian figure. Despite a few misprints or errors, Penner's work is a well-researched study which demonstrates how literary culture permeated many other discourses in the Victorian period.

\section{INDEX}

Keywords: Victorian medicine, health, social reform

Mots-clés: médecine, santé

\section{AUTHORS}

\section{LAURENCE TALAIRACH-VIELMAS}

Professeur

Université Toulouse 2 - Le Mirail

talairac@univ-tlse2.fr 